\title{
SELF-CONSISTENT ESTIMATES OF EMISSION FACTORS OF CARBON- CONTAINING POLLUTANTS FROM A TYPICAL GAS FLARE
}

\author{
Fawole, O. G. ${ }^{1,2 *}$, Cai, X. -M. ${ }^{2}$, Nikolova, I. ${ }^{2}$, MacKenzie, A. R. ${ }^{2,3}$ \\ ${ }^{1}$ Environmental Pollution Research Laboratory (EPRL), Department of Physics and Engineering Physics, Obafemi \\ Awolowo University, Ile-Ife, Nigeria 220005 \\ ${ }^{2}$ School of Geography, Earth and Environmental Sciences, University of Birmingham, Edgbaston, Birmingham, B15 \\ 2T'T, UK \\ ${ }^{3}$ Birmingham Institute of Forest Research, University of Birmingham, Edgbaston, Birmingham, B15 2TT, UK \\ *Corresponding author: gofawole@oauife.edu.ng \\ (Received: $5^{\text {th }}$ November, 2019; Accepted: $5^{\text {th }}$ June, 2020)
}

\section{ABSTRACT}

\begin{abstract}
This study proposes an approach for estimating the emission of soot, carbon monoxide (CO) and carbondioxide $\left(\mathrm{CO}_{2}\right)$ from a typical gas flare. The estimations depend on the quantity and varying composition of the natural gas, flame dynamics (represented by the fire Froude number, $F r_{f}$ ) and the equivalence ratio, $\phi$, of the fuelair mixture. Soot emission estimates are presented as a function of fire Froude number for gases used in labbased test in order to validate the scheme and for two real-world fuel gas compositions. The mass-weighted carbon-hydrogen ratio (C:H) of the fuel gas compositions are 0.25 and 0.29 which are two extreme cases in terms of density. The soot yield of the lab-based test case was scaled up to estimate the soot yield of a full scale flare using the Richardson number as the scaling parameter. When all other variables are held constant at values characteristics of real-world flares, a difference of $16 \%$ in the fuel-gas density, as indicated by the carbonhydrogen ratio, results in an increase of the emission factors (EF) of soot, $\mathrm{CO}$ and $\mathrm{CO}_{2}$ by factors of $\sim 3, \sim 1.4$ and $\sim 1.7$, measured in $\mathrm{g} / \mathrm{m}^{3}$, respectively. For both fuel gas compositions, the ratio of $E F_{\text {soot }}$ to $E F_{C O}$ at the fuellean region $\phi<1)$ is higher. The ratio lies in the range $0.031-0.13$ and $0.0012-0.0055$ for the fuel-lean $(\phi<1)$ and fuel-rich $(\phi>1)$ regions, respectively. The approach proposed and results obtained may be adopted to generate emissions inventories of emission species associated with gas flaring on regional and global scales.
\end{abstract}

Keywords: gas flaring; soot; natural gas; emission factor; black carbon; equivalence ratio

\section{INTRODUCTION}

Natural gas comprises mainly of hydrocarbons occurring in geological deposits, and consists mainly of methane. It includes both "nonassociated" gas, originating from fields producing hydrocarbons only in gaseous form, and "associated" gas, produced in association with crude oil and separated at a flow station (IEA, 2012). Gas flaring and booming are the widely used methods of disposing of some of these gases, which are often termed unwanted or hazardous. Gas flaring is the controlled burning, in open flame, of associated gas that is produced at various stages of crude oil exploration and exploitation (Beychok, 1994; EEA, 2006). For the purpose of this study, the flared gas will be referred to as fuel gas. In recent years, especially 2014 - 2016, there had been renewed efforts at the estimation of emissions from gas flaring activities as well as quantifying the contributions of gas flaring to atmospheric pollution, particularly in the Bakken region of North Dakota, USA and the
Arctic (Li et al., 2016; Schwarz et al., 2015; Weyant et al., 2016).

While carbon dioxide $\left(\mathrm{CO}_{2}\right)$ is an inevitable consequence of flaring, a number of undesired pollutants are emitted during gas flaring process. The undesirable pollutants are emitted when the combustion process is inefficient or incomplete as a result of incomplete oxidation of hydrocarbon species in the fuel gas or the ineffectiveness of the process (Flagan and Seinfeld, 2012; Fortner et al., 2012). Globally, about 140 billion cubic meters (bcm) of gas was flared in 2011, an increase of 1.9 $\%$ from the preceding year (GGFR, 2012). This represents an estimated contribution of 350 million tons of $\mathrm{CO}_{2}$ to global greenhouse gas (GHG) emissions. Noise, smoke (soot), heat radiation, nitrogen oxides $\left(\mathrm{NO}_{\mathrm{x}}=\mathrm{NO}+\mathrm{NO}_{2}\right)$, carbon monoxide $(\mathrm{CO})$, sulfur dioxide $\left(\mathrm{SO}_{2}\right)$ and Polycyclic Aromatic Hydrocarbons (PAH) are some of the environmental contaminants released during gas flaring process (Abdulkareem et al., 
2012; Almanza et al., 2012; Johnson and Kostiuk, 2000; Kostiuk et al., 2004; McDaniel and Tichenor, 1983; Obanijesu et al., 2009; Sonibare et al., 2010; Stone et al., 1992).

The nature and quantity of pollutants given off during the combustion process depend on a number of factors which include air-fuel mass (or mole) ratio, fuel gas composition, fuel flow rate, mixing of fuel gas and air, efficiency of the burner and prevailing ambient meteorology (Castineira and Edgar, 2006; Fortner et al., 2012; Ismail and Umukoro, 2016; Sivathanu and Faeth, 1990; Sonibare and Akeredolu, 2004; Talebi et al., 2014; Torres et al., 2012a; Torres et al., 2012b). Studies have identified gas flaring as a prominent contributor to regional air pollution index especially in oil-producing regions of the world (Edwards et al., 2014; Fawole et al., 2016; Fawole et al., 2017; Gilman et al., 2013; Liousse et al., 2019). About $1-8 \%$ of global, $15-30 \%$ of oil-rich regions and more than $50 \%$ of Arctic black carbon (BC) emission could be attributed to gas flaring (Huang et al., 2015; Stohl et al., 2013).

Estimates of emission factors (EF) from gas flaring have been made using pilot-scale studies (McDaniel and Tichenor, 1983; Talebi et al., 2014), lab-based studies (McEwen and Johnson, 2012), simulations (Almanza et al., 2012; Ismail and Umukoro, 2016; Sonibare and Akeredolu, 2004) and field measurements (e.g., Sky-LOSA technique) (Johnson et al., 2013; Johnson et al., 2011).

Black carbon (BC), a principal light-absorbing species in the atmosphere has been identified as the second major contributor to global warming after $\mathrm{CO}_{2}$ Santos et al., 2014). Fossil fuel-derived $\mathrm{BC}$ has equally been identified as a stronger global warming agent than biomass-derived BC (Bond et al., 2013; Ramana et al., 2010; Ramanathan and Carmichael, 2008). BC may also contribute significantly to visibility degradation (Feichter and Stier, 2012; Jacobson, 2002; Seinfeld, 2008; Tegen et al., 1997). It also contribute a large fraction to the fine particulate mass (PM) fraction found in ambient air especially around highly populated and industrialized regions of the world (Chow et al., 1996; Kirchstetter et al., 1999).
Measuring soot (BC) yield in an open fire like gas flare is a difficult task (Johnson et al., 2011). However, attempts have been made to quantify soot yield in terms of the fuel and fire characteristics, flow conditions and burner geometry in pilot-scale and lab-based studies (Becker and Liang, 1982; Delichatsios, 1993; Sivathanu and Faeth, 1990). Carbon conversion efficiency (CCE) is a measure of the extent of conversion of the carbon content of the fuel gas to carbon dioxide, usually expressed as a percentage (Bourguignon et al., 1999). CCE is often used to determine the completeness of combustion and it can be as low as $62 \%$ in associated gas flares (Strosher, 2000). At a CCE of about $99 \%$, visible smoking can still be observed in a flare (Siegel, 1980). The carbon content of the fuel gas could be emitted as carbon dioxide, carbon monoxide, total hydrocarbon (THC) and BC. The amount of each fraction emitted depends on the degree of completeness of the combustion which could be estimated from the CCE.

This work aims to develop a simple self-consistent method which requires fewer inputs from the user and takes into account the flame dynamics to study the variation of $\mathrm{CO}, \mathrm{CO}_{2}$ and soot emission with varying fuel gas composition, flow characteristics, stack geometry and equivalence ratio in a typical gas flare. The characteristic physical and chemical parameters defining the flare are first introduced and are then used to derive a system of equations to estimate the EFs. The approach is validated by comparing the model outputs with results from similar test flares from literature. Finally, variation of EFs with realistic changes in fuel composition is examined and possible implication of results from the study on global emission inventories is discussed.

\section{METHODOLOGY}

\section{Equivalence Ratio}

For the purpose of this work, the degree of combustion is determined in terms of the amount of oxygen available for the combustion of the fuel gas which is measured as air to fuel mass ratio. The stoichiometric air-fuel ratio gives the theoretical proportion of air mass needed for the complete combustion of the fuel where $A, F$ and $s$ denote 
'air', 'fuel' and 'stoichiometric mixture', respectively. During combustion, stoichiometric mixture is not always and everywhere attained, hence, it is necessary to calculate the actual air to fuel ratio , where a denotes 'actual mixture' (Flagan and Seinfeld, 2012). Equivalence ratio $(\phi)$ is defined as:

$\phi=\frac{\left(\frac{A}{F}\right)_{s}}{\left(\frac{A}{F}\right)_{a}}$

Thus $\phi=1$ is a stoichiometric, $\phi<1$ a fuel-lean (under-fired) and $\phi>1$ a fuel-rich (over-fired) mixture.

The quantity of combustion products, especially soot, varies significantly with the equivalence ratio, $\phi$ (Huang et al., 2015). When $\phi<1$ (excess air), combustion could be assumed to be complete with excess oxygen given off unreacted as a combustion by-product (Flagan and Seinfeld, 2012; McAllister et al., 2011). The combustion products for an 'ideal' combustion $(\phi=1)$ are relatively easy to quantify as $\mathrm{CO}_{2}$, water and fully oxidized products of any trace components (e.g., $\mathrm{N}_{2}$ and $\mathrm{H}_{2} \mathrm{~S}$ converted to $\mathrm{NO}_{2}$ and $\mathrm{SO}_{2}$, respectively). Complete combustion is often not achieved in most flaring conditions as pyrolysis converts some of the fuel gas to many complex chemical species rather than the 'ideal' $\mathrm{CO}_{2}, \mathrm{SO}_{2}$, $\mathrm{NO}_{2}$ and $\mathrm{H}_{2} \mathrm{O}$ (Leahey et al., 2001; Strosher, 2000).

The products of combustion for $\phi>1$ are more difficult to specify and estimate because there is not enough oxygen to completely burn off all of the fuel gas (Flagan and Seinfeld, 2012; McAllister et al., 2011). Higher values of $\phi$ give rise to cooler flames that do not support fast combustion kinetics and, hence, favour the production of sooty flames (Stone et al., 1992). Lower flame temperature reduces the buoyancy and mixing of fuel gas and air in the combustion zone (Stone et al., 1992) with implications on how the emissions are dispersed into the ambient atmosphere.

\section{Mole balancing equation}

For an 'ideal' stoichiometric mixture $(\phi=1)$ of a hydrocarbon (alkane) and air, the generalized equation for complete combustion is:
$\mathrm{C}_{x} \mathrm{H}_{y}+\left(\frac{y}{4}+x\right) \mathrm{O}_{2} \rightarrow x \mathrm{CO}_{2}+\left(\frac{y}{2}\right) \mathrm{H}_{2} \mathrm{O}$

where ' $x$ ' and ' $y$ ' are integers, the relationship between which defines the hydrocarbon. For a mixture of various hydrocarbons, as in fuel gas, ' $x$ ' and ' $y$ ' are real numbers calculated from the molar composition of the gas. In a first step away from ideality, these calculated values of ' $x$ ' and ' $y$ ' can be scaled to take account of unburnt hydrocarbon. Taking into account the effects of the equivalence ratio (which is treated henceforth as an empirical input) and incomplete oxidation, as discussed above, a generalized combustion equation (GCE) is proposed as:

$C_{x} H_{y}+\frac{1}{\phi}\left(\frac{y}{4}+x\right) O_{2} \rightarrow p \mathrm{CO}_{2}+q \mathrm{CO}+r C+v \mathrm{O}_{2}+\left(\frac{y}{2}\right) \mathrm{H}_{2} \mathrm{O}$

where ' $p$ ', ' $q$ ', ' $r$ ' and ' $v$ ' are real numbers whose values are determined by the degree of completeness of oxidation achieved in the flame. In forming equation (3), it is assumed that all hydrogen is converted to water. Hence, all black carbon is made up purely of elemental carbon and no PAH is emitted. The parameter ' $v$ ' in equation (3), number of moles of 'unused' oxygen, is defined to ensure that all molar quantities are positive definite.

From equation (3), the following conservative relations can be obtained:

$x=p+q+r$

$\frac{1}{\phi}\left(x+\frac{y}{4}\right)=p+\frac{q}{2}+v+\frac{y}{4}$

From equations (4a) and (4b);

$q=\left(2 x+\frac{y}{2}\right)\left(1-\frac{1}{\phi}\right)+2 v-2 r$

$=2\left(x+\frac{y}{4}\right)\left(1-\frac{1}{\phi}\right)+2 v-2 r$

$=2($ OCOM $)\left(1-\frac{1}{\phi}\right)+2 v-2 r$

$p=N C A R-q-r$

$=N C A R-\left(2(O C O M)\left(1-\frac{1}{\phi}\right)+2 v-2 r\right)-r$

where NCAR $=x$ is the number of carbon atom in the hydrocarbon specie and OCOM the number of moles of oxygen requires by the hydrocarbon specie for stoichiometric mixture.

For $\phi>1$, it is assumed that $v=0$ (i.e. no unused 
oxygen)

Hence $q=\left(2 x+\frac{y}{2}\right)\left(1-\frac{1}{\phi}\right)-2 r$

For $\phi \leq 1 ; v \neq 0$

Incomplete combustion of natural gas gives off $\mathrm{CO}$ and $\mathrm{CO}_{2}$ in ratios which depend on the source and efficiency of the combustion process (Djuricin et al., 2010). Formation of CO depends majorly on the amount of air available - lesser or in excess - for the combustion process (Bishop and Stedman, 1996). For gas flaring, the ratio of the emission factor of $\mathrm{CO}$ to that of $\mathrm{CO}_{2}$ obtained from literature are 0.0024 (EEMS, 2008), 0.0032 (USEPA, 2014) and 0.0042 (UK Offshore Association see (Talebi et al., 2014)). For this work, the USEPA value of 0.0032 will be used as it was obtained from a pilot study carried out on emissions from gas flares. From (USEPA, 2014),

$\frac{E F_{c o}}{E F_{c o 2}}=\frac{M_{c o} q}{M_{c o 2} p}=0.0032$

where $M_{c o}$ and $M_{c o 2}$ are the molar mass on CO and $\mathrm{CO}_{2}$, respectively.

$\frac{q}{p}=0.005$

$\frac{q}{p}=\frac{2(\text { OCOM })\left(1-\frac{1}{\phi}\right)+2 v-2 r}{N C A R-2(O C O M)\left(1-\frac{1}{\phi}\right)-2 v+r}=0.005$

Hence;

$v=\frac{0.005 N C A R-2.01 * \text { OCOM }\left(1-\frac{1}{\phi}\right)+2.005 r}{2.01}$

$\left.\begin{array}{l}v=\frac{0.005 N C A R+2.005 r}{2.01} \\ q=2 v-2 r\end{array}\right\} \phi=1$

Therefore, there are three equations $(4 \mathrm{a}, 4 \mathrm{~b}$ and $5 b)$ relating four unknowns $(p, q, r, v)$ and three input parameters $(x, y, \phi)$ which are insufficient to evaluate $p, q, r$ and $v$. One further relationship is required.
In this study, a method is developed using the fire Froude number, Fr suggested by Delichatsios (1993) and improved upon by McEwen and Johnson (2012) as a basis to constrain parameter, $r$, for the 'unburned' carbon. In their experimental study, McEwen and Johnson (2012) plotted soot yields as a function of the fire Froude number (see Fig. 1). In this study, the soot yield from the lab-based experiment of McEwen and Johnson is scaled up to estimate the soot yield from a full-scale flare using a scaling parameter (Becker and Liang, 1982; Canteenwalla et al., 2007). The scaled-up soot yield data is then used to constraint the term ' $r C$ in the GCE (see equation 3) and ' $r$ ' in eq. (5b) and, hence, obtain ' $p$ ', and ' $q$ '.

Fire Froude number, $F r_{f}$ (eq. 6 ) is a dimensionless parameter related to the flame dynamics characteristics.

$\mathrm{Fr}_{f}=\frac{\mathrm{u}_{\mathrm{e}} \mathrm{f}_{\mathrm{s}}^{3 / 2}}{\left(\frac{\Delta \mathrm{T}_{\mathrm{f}}}{\mathrm{T}_{\mathrm{amb}}} \mathrm{gd}_{\mathrm{e}}\right)^{1 / 2}\left(\frac{\rho_{\mathrm{e}}}{\rho_{\mathrm{a}}}\right)^{1 / 4}}$

where $\frac{1}{s+1}=\frac{\phi}{\left(\frac{\phi}{f}\right)_{s}+\phi}$

$s$-air-fuel mass ratio, $\left(\frac{a}{f}\right){ }_{a}$

$u_{e}-$ flue gas exit velocity $(\mathrm{m} / \mathrm{s})$

$T_{a m b}-$ ambient temperature $(\mathrm{K})$

$T_{\theta}$-adiabatic temperature $(\mathrm{K})$, defined below

$\Delta T_{f}$ - flame temperature rise $\left(\Delta \mathrm{T}_{\mathrm{f}}=\mathrm{T}_{\theta}-\mathrm{T}_{\mathrm{amb}}\right)(\mathrm{K})$

$g-$ acceleration due to gravity $\left(\mathrm{m} / \mathrm{s}^{2}\right)$

$d_{e}$-stack diameter $(\mathrm{m})$

$\rho_{\diamond} \rho_{e}-$ ambient and fuel gas density respectively $\left(\mathrm{kg} / \mathrm{m}^{3}\right)$ 


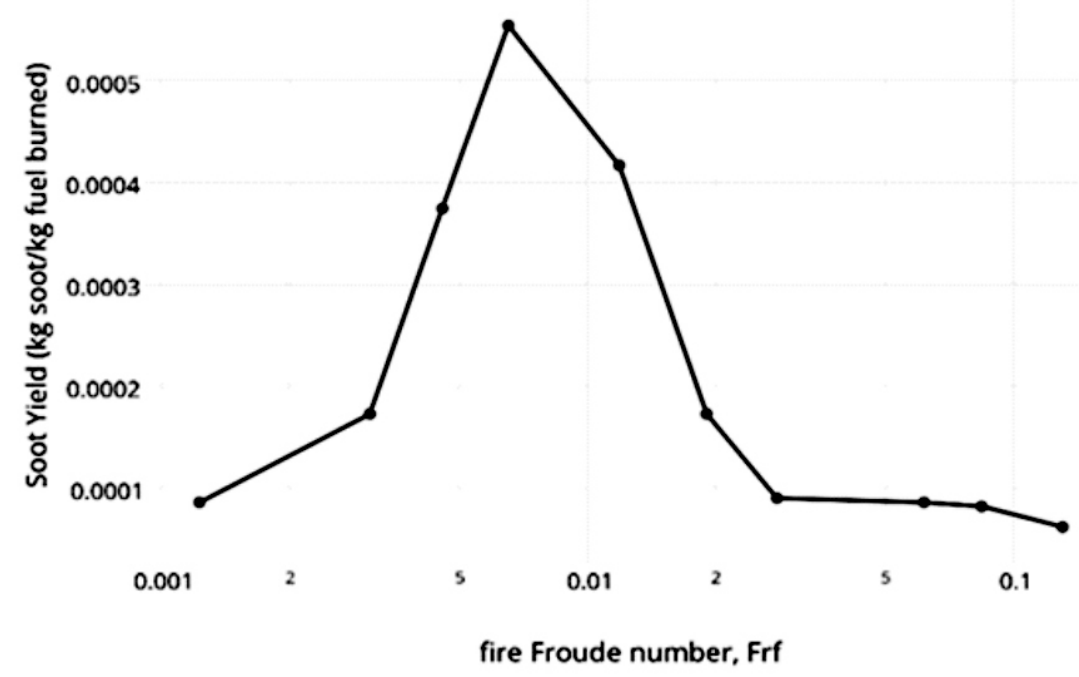

Figure 1: Soot yield as a function of fire Froude number (adapted from (McEwen and Johnson, 2012))

For this study, $F r_{f}$ of the combustion flame is dependent on the air-fuel mass ratio and hence on one of our variable, the equivalence ratio, $\phi$. The adiabatic temperature, $T_{\theta}$, for the different combustion type and fuel compositions is calculated as the roots of the quadratic in eq. (7).

$h_{i}\left(T_{\theta}\right)-h_{i}\left(T_{a m b}\right)=a_{i}\left(T_{\theta}-T_{a m b}\right)+\frac{b_{i}}{2}\left(T_{\theta}^{2}-T_{a m b}^{2}\right)$

where $h_{i}$ is the temperature-dependent molar specific enthalpy for the $i$ th species of hydrocarbon; $T_{\theta}$ and $T_{a m b}$ are the adiabatic and ambient temperature respectively; and $a_{i}$ and $b_{i}$ are thermodynamic constant given in $\mathrm{J} \mathrm{mol}^{-1} \mathrm{~K}^{-1}$ (available from electronic databases and handbook such as JANAF thermochemical tables). Equation (7) is adapted from Flagan and Seinfeld (2012).

For this model, the typical range of adiabatic temperatures obtained for various fuel compositions fall in the range $1900-2440 \mathrm{~K}$. Use of equations (6) and (7) means that a further input parameter, $T_{\text {amb }}$ must be supplied. The appearance of ambient temperatures in equations (6) and (7) is also the first appearance of environmental condition in the problem, indicating that the geographical context of flaring may be significant in determining emission factors.

To fully relate the soot yield in Fig. 1 to our proposed input parameters $\left(\mathrm{x}, \mathrm{y}, \phi, T_{\mathrm{amb}}\right)$, it is necessary to consider the difference between the test flame in the study by McEwen and Johnson relative to real-world gas flares. It should be noted that the chemistry of soot depend sensitively on the composition of the fuel (Kostiuk et al., 2004) and fuel gas with high carbon to hydrogen ratio has a greater tendency to smoke (Akeredolu and Sonibare, 2004). The fuel used in McEwen and Johnson (2012) is made up of four alkane species $\left(\mathrm{CH}_{4}, \mathrm{C}_{2} \mathrm{H}_{6}, \mathrm{C}_{3} \mathrm{H}_{8}\right.$ and $\left.\mathrm{nC}_{4} \mathrm{H}_{10}\right)$ with methane $\left(\mathrm{CH}_{4}\right)$ being $85.24 \%$ by volume of the fuel gas. The carbon to hydrogen ratio of the fuel used by McEwen and Johnson (2012) is $\sim 0.25$, a value less than $0.27-0.29$ for typical fuel composition in real-world gas flares (Fawole et al., 2016).

\section{Soot scaling parameter}

Lab-based study of emissions from flares is the most common and readily available method to estimate emissions from full-scale flares. Considering the size (diameter) of stack, higher fuel flow flux, and invariably the flue gas exit velocity of full-scale flares, there is the need to apply a scaling parameter to lab-based flare emission yields in order to estimate the yield from a full-scale flare (Fawole et al., 2016). In previous studies, Richardson ratio (Becker and Liang, 1982), flame length (Schug et al., 1980) and Damkohler ratio (characteristic residence time) (Sivathanu and Faeth, 1990) are parameters that have been considered for such scaling purposes. 
In the present work, the Richardson ratio, $R i_{L}$, is used to scale up the soot yield data from the labbased study by McEwen and Johnson (2012). Richardson ratio $R i_{I}$, as defined by Becker and Liang (1982) (eq. 8) was adopted because it involves the buoyancy of the flame which is a parameter also considered in fire Froude number, $\mathrm{Fr}_{f} \mathrm{R} i_{L}$ also has a good correlation with soot emission from propane flame (Becker and Yamazaki, 1978).

$\mathrm{Ri}_{\mathrm{L}}=\frac{\text { buoyancy of flame }}{\text { source momentum flux }} \cong \frac{\pi \mathrm{g} \rho_{\infty} \mathrm{L}^{3}}{\rho_{\mathrm{e}} \mathrm{AV} \mathrm{e}^{2}}$

where L - flame length (m)

$\mathrm{g}$-acceleration due to gravity $\left(\mathrm{m} / \mathrm{s}^{2}\right)$

A - cross-sectional area of stack $\left(\mathrm{m}^{2}\right)$

$\mathrm{V}_{\mathrm{e}}$ - flue gas exit velocity $(\mathrm{m} / \mathrm{s})$

$\rho_{\infty}, \rho_{e}-$ density of ambient air and flue gas, respectively $\left(\mathrm{kg} / \mathrm{m}^{3}\right)$

$\mathrm{R} i_{L}$ varies with fuel composition as a result of the dependence of flame length, $L$, on the net heat released by the fuel during combustion.

For $F r_{f}=0.005$, the soot yield in the experiment by McEwen and Johnson (2012) is $0.42 \mathrm{~g}$ of soot $/ \mathrm{kg}$ of fuel burned (see Fig.1). For the same value of $\mathrm{Fr}_{f}$ the scaled-up values of soot yield are 0.79 and $1.11 \mathrm{~g}$ of soot $/ \mathrm{kg}$ of fuel burned for fuel compositions I and II, respectively. The model calculates the fire Froude number, $F r_{f}$ from the inputs $\left(\mathrm{x}, \mathrm{y}, \phi, T_{a m b}, \rho_{a}, g, d\right)$ supplied by the user. The calculated $F r_{f}$ is used to estimate total soot yield from the scaled-up experimental soot yield data.

If, for the sake of simplicity and in the absence of a more process-based structural relationship, we assume that the soot yield per component, $\chi_{i}$ of a fuel mix of $n$ hydrocarbon components is simple linear function of the contribution of hydrocarbon $i$ to the overall (non- $\mathrm{CO}_{2}$ ) carbon budget, then we have:

$\chi_{i}=\frac{C_{i} F_{i}}{\sum_{j=1}^{n} C_{j} F_{j}} \cdot S_{i} \cdot \chi_{\text {Tot }}$

In Eq. (9), $C_{i}$ is the number of carbon atoms in the empirical formula of component $I, F_{i}$ is the volume fraction of component $I$, and $X_{T o t}$ is the total soot yield from the flame. The parameter $S_{i}$ is a dimensionless empirical function (such as the Richardson ratio described above) which accounts for the greater propensity of a full-scale flare to soot as a result of the stack size, flame characteristics and fuel gas flow characteristics.

\section{RESULTS AND DISCUSSION}

\section{Soot Yield}

The two fuel compositions given in Table 1 have been used to evaluate the effect of fuel composition of the EFs. Other parameters such as the fuel gas densities and molar masses are also provided in Table 1 . The ambient temperature $(298 \mathrm{~K})$, stack diameter $(0.75 \mathrm{~m})$ and atmospheric pressure $\left(1.0133 \times 10^{5} \mathrm{~Pa}\right)$ are kept constant during the calculation.

Table 1: Fuel compositions used in this study (given in molar percentage)

\begin{tabular}{|c|c|c|}
\hline & I & II \\
\hline $\mathbf{C H}_{4}$ & 88.72 & 69.58 \\
\hline $\mathbf{C}_{2} \mathbf{H}_{6}$ & 5.93 & 0.25 \\
\hline $\mathbf{C}_{3} \mathbf{H}_{8}$ & 1.28 & 12.54 \\
\hline $\mathbf{n C}_{4} \mathbf{H}_{10}$ & 0.26 & 2.35 \\
\hline $\mathbf{i C}_{4} \mathbf{H}_{10}$ & 0.26 & 5.12 \\
\hline $\mathbf{n C}_{5} \mathbf{H}_{12}$ & 0.06 & 5.20 \\
\hline $\mathbf{i C}_{5} \mathbf{H}_{12}$ & 0.09 & 2.54 \\
\hline $\mathbf{C}_{6} \mathbf{H}_{14}$ & 0.06 & 1.97 \\
\hline $\mathbf{C}_{7} \mathbf{H}_{16}$ & 0.1 & - \\
\hline $\mathbf{N}_{2}$ & 0.66 & 0.24 \\
\hline $\mathbf{C O}_{2}$ & 2.55 & 0.21 \\
\hline $\mathbf{H}_{2} \mathbf{S}$ & 0.03 & - \\
\hline $\mathbf{C} \mathbf{~ H}$ & 0.25 & 0.29 \\
\hline $\mathbf{H H V} * \mathbf{( k J} / \mathbf{m o l})$ & 939.8 & 1480.4 \\
\hline Molar $\mathbf{m a s s} \mathbf{( g} / \mathbf{m o l})$ & 18.5 & 28.6 \\
\hline Density $\left.\mathbf{( k g} / \mathbf{m}^{3}\right)$ & 0.75 & 1.2 \\
\hline & \multicolumn{2}{|c}{} \\
\hline \multicolumn{2}{|c}{} \\
\hline
\end{tabular}


For fuel composition I, at $\phi=1.0$, the fire Froude number $F r_{f}=0.0045$. Scaling down the soot yields for each hydrocarbon species in the fuel gas by their percentage molar concentration in the fuel gas, gives a total soot yield of $0.0143 \mathrm{~g} / \mathrm{mol}$ of the fuel gas under the conditions stated above.

$E F_{\text {soot }}=$ total soot yield $(\mathrm{g} / \mathrm{mol}) \times$ molar density of fuel $\left(\mathrm{mol} / \mathrm{m}^{3}\right)$

Hence, estimated $E F_{\text {soot }}=0.58 \mathrm{~g} / \mathrm{m}^{3}$ (equivalent to $0.00076 \mathrm{~kg}$ of soot $/ \mathrm{kg}$ of fuel burned). And, for a flow flux $=1.174 \mathrm{~m}^{3} / \mathrm{s}$, the soot emission rate (ER) is $0.69 \mathrm{~g} / \mathrm{s}$.

For fuel composition II under the same condition, the estimated $E f_{\text {soot }}=1.73 \mathrm{~g} / \mathrm{m}^{3}$. This is equivalent to $0.0015 \mathrm{~kg}$ of soot/ $\mathrm{kg}$ of fuel burned and an emission rate of $2.03 \mathrm{~g} / \mathrm{s}$ for the same fuel flow flux.

In the estimation proposed in this work, the percentage of carbon content of the fuel gas that ends up as soot for $0.8 \leq \phi \leq 1.3$ ranges between 0.1 and $0.35 \%$ (by mass) which is in consonance with less than $0.4 \%$ found out by Kostiuk et al. (2004) in their pilot study carried out in the University of Alberta, Canada. The CCE for the various fire and fuel characteristics used in this study is between 99.5 and $33.7 \%$ (see Figures 4 and 5 for the variation of CCE with $\phi)$.

\section{Carbon monoxide yield}

For a fuel gas made up of $\mathrm{N}$ alkane species, the emission factor for carbon monoxide $\left(E F_{C O}\right)$ is estimated as:

$E F_{c o}=\frac{n_{c o}}{n_{\text {fuel gas }}} \frac{P M_{c o}}{R T}$

where $\frac{n_{c o}}{n_{\text {fuel gas }}}=\sum_{i}^{N} q_{i} c_{i}$

$P$-atmospheric pressure $(\mathrm{Pa})$

$\mathrm{R}$ - universal gas constant $\left(\mathrm{m}^{3} \mathrm{~Pa} / \mathrm{K} \cdot \mathrm{mol}\right)$

$M_{C O}$ - molar masses of $\mathrm{CO}(\mathrm{g} / \mathrm{mol})$

$T$-ambient temperature $(\mathrm{K})$

$q_{i}$ and $c_{i}$ - the CO yield and percentage molar concentration of species $i$ in the fuel gas.

Under the combustion conditions given above for soot, for fuel gas composition I $\frac{n_{\text {co }}}{n_{\text {fuel gas }}}=0.0054$

By eq. (10), this gives $E F_{C O}=6.16 \mathrm{~g} / \mathrm{m}^{3}$ (equivalent to $0.0082 \mathrm{~kg} / \mathrm{kg}$ of fuel burned). For fuel flow flux $=1.174 \mathrm{~m}^{3} / \mathrm{s}, \mathrm{ER}=7.2 \times 10^{-3} \mathrm{~kg} / \mathrm{s}$.

For composition II:

$\frac{n_{C O}}{n_{\text {fuel gas }}}=0.0093$

Hence, $E F_{C O}=10.69 \mathrm{~g} / \mathrm{m}^{3}$ (equivalent to 0.0092 $\mathrm{kg} / \mathrm{kg}$ of fuel burned and $\left.1.3 \times 10^{-2} \mathrm{~kg} / \mathrm{s}\right)$.

\section{Carbon dioxide yield}

$E F_{c o 2}=\frac{n_{c o 2}}{n_{\text {fuel gas }}} \frac{P M_{c o 2}}{R T}$

where $\frac{n_{c o 2}}{n_{\text {fuel gas }}}=\sum_{i}^{N} p_{i} c_{i}$

$M_{\mathrm{CO}_{2}}-$ molar masses of $\mathrm{CO}_{2}(\mathrm{~g} / \mathrm{mol})$

pi and ci - the $\mathrm{CO}_{2}$ yield and percentage molar concentration of species $i$ in the fuel gas.

Under the combustion conditions given above, for fuel gas composition I:

$\frac{\mathrm{n}_{\mathrm{CO}_{2}}}{\mathrm{n}_{\text {fuel gas }}}=1.10$

By eq. (11), this gives $E F_{C O 2}=1.98 \mathrm{~kg} / \mathrm{m}^{3}$ (equivalent to $2.62 \mathrm{~kg} / \mathrm{kg}$ of fuel burned and 2.32 $\mathrm{kg} / \mathrm{s}$ )

For composition II:

$\frac{\mathrm{n}_{\mathrm{CO}_{2}}}{\mathrm{n}_{\text {fuel gas }}}=1.86$

Hence, $E F_{C O 2}=3.35 \mathrm{~kg} / \mathrm{m}^{3}$ (equivalent to 2.87 $\mathrm{kg} / \mathrm{kg}$ of fuel burned and $3.93 \mathrm{~kg} / \mathrm{s}$ )

For the 10 different fuel gas compositions obtained from Sonibare and Akeredolu (2004), the relationships between their soot yield, molar masses and higher heating values (HHV) are presented in Fig. 2. The soot yields and HHV of these fuel gas compositions are estimated from this model for $\phi=1$. It should be noted that HHV can only be calculated at $\phi=1$ because HHV is the amount of heat given off by the complete combustion of a fuel. For these fuels, the range of the molar mass and HHV are 18 - 28.6 and 39.960.3 , respectively. 

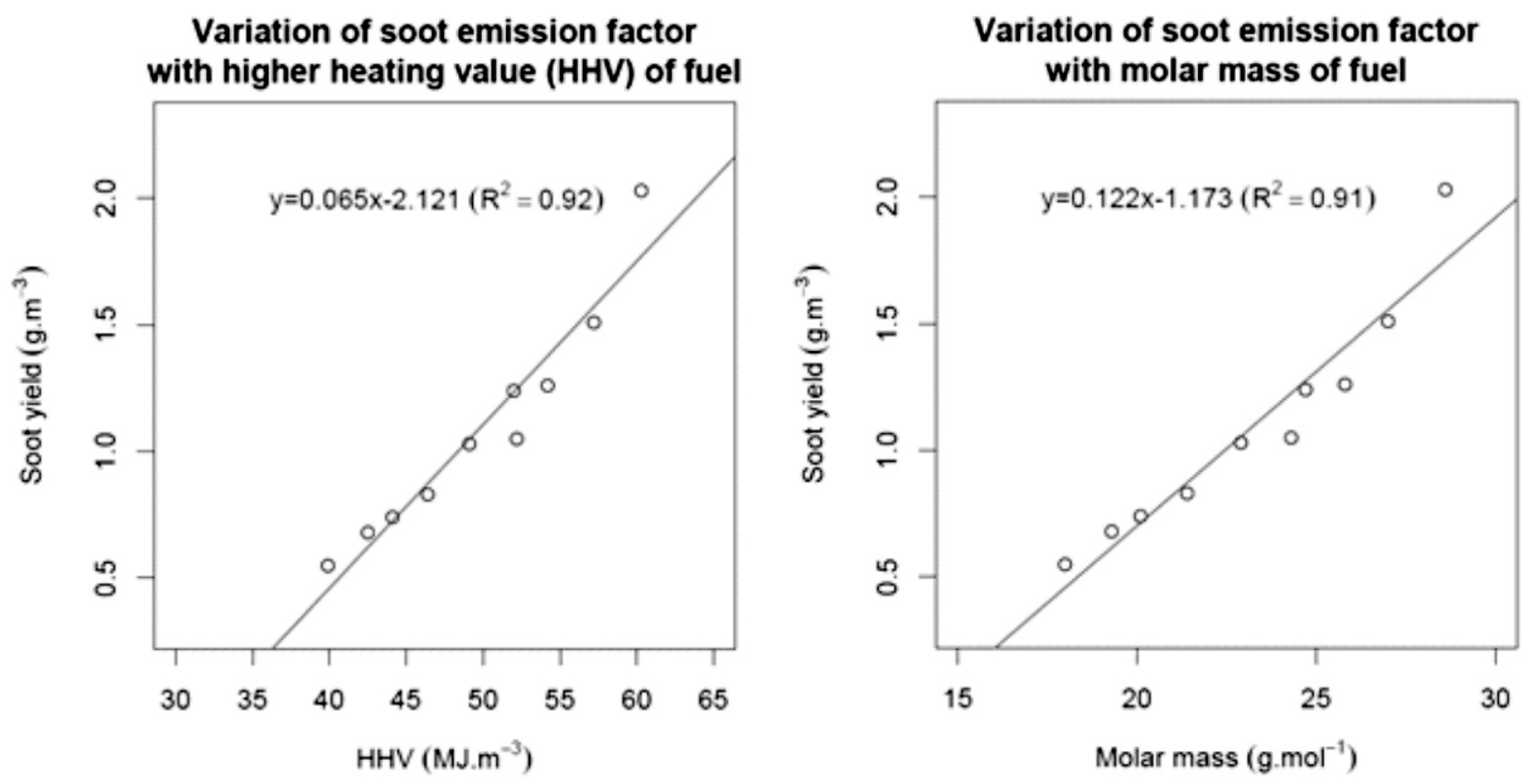

Figure 2: Relationship between $\mathrm{EF}_{\text {soot }}$ molar mass and $\mathrm{HHV}$ for some fuel compositions

For this study, it is assumed that the carbon content of the fuel gas ends up as $\mathrm{CO}_{2}, \mathrm{CO}$ and soot. Hence, eliminating the presence of $\mathrm{PAH}$ and other incompletely oxidized hydrocarbon from the loop. For the denser fuel composition (composition II), the variation of $\mathrm{CO}_{2}, \mathrm{CO}$ and soot with equivalent ratio, $\phi$ is shown in Fig. $3 \mathrm{a}$ while Fig. $3 \mathrm{~b}$ shows the variation of $\mathrm{CO}$ to $\mathrm{CO}_{2}$ ratio with $\phi$ where the gradient gets steeper as $\phi$ increases but plateaued when $\phi<1$.
A comparison of the EF estimates from this study with those obtained from similar study from literature - lab-based, pilot study, field measurement and calculations - are presented in Tables $2 \mathrm{a}$ and $2 \mathrm{~b}$. It should be noted, however, that this work considered two very different fuel compositions (light and dense). As such, two different EFs will be quoted for comparison in the tables below. (a)

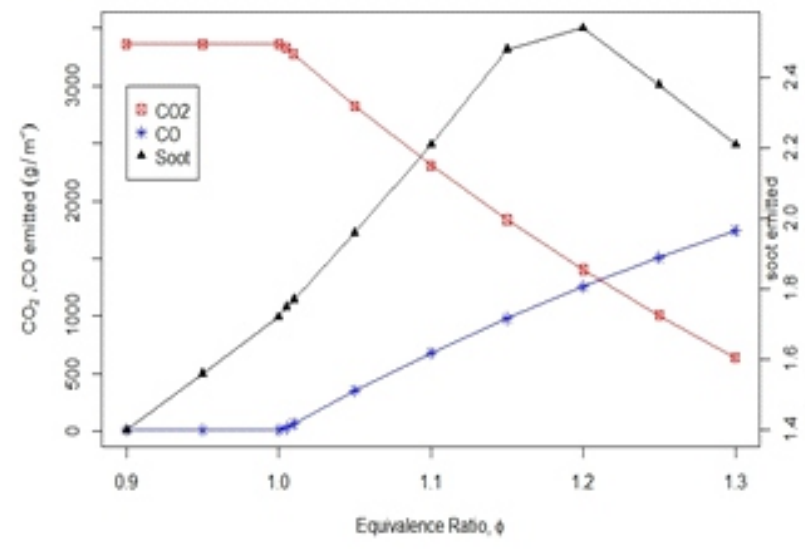

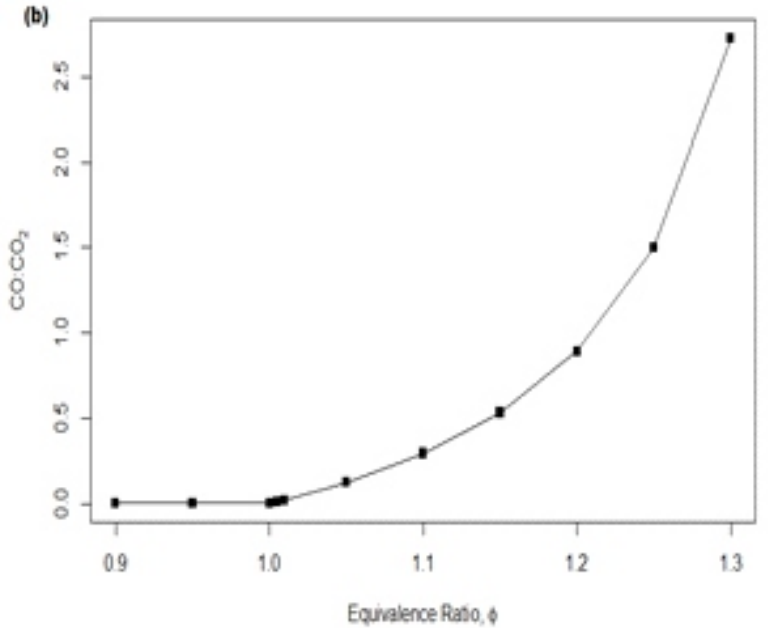

Figure 3: (a) Relationship between equivalence ratio $(\phi), E F_{C O 2}, E F_{C O}$ and $E F_{\text {soot }}$ (b) variation of $\mathrm{CO}: \mathrm{CO}_{2}$ with $\phi$. 
The method developed here produced EFs and emission rates (ERs) that compare favourably well with those obtained from similar studies in literature. ER is the product of $\mathrm{EF}\left(\mathrm{g} / \mathrm{m}^{3}\right)$ and fuel flow flux $\left(\mathrm{m}^{3} / \mathrm{s}\right)$. Fuel flow flux varies significantly from one field to another and can be as high as $32.3 \mathrm{~m}^{3} / \mathrm{s}$, the estimated value for an active flare in Venezuela which is ranked \#1 globally (Elvidge et al., 2015). In this model, $E F_{\text {soot }}$ of 0.58 and 1.73 $\mathrm{g} / \mathrm{m}^{3}$ obtained for fuel I and II, respectively, fall within the light- and averagely-smoking flare category for USEPA (1995). For soot, emission rates of $6.9 \times 10^{-4}$ and $2.02 \times 10^{-3} \mathrm{~kg} / \mathrm{s}$ obtained for fuel I and II, respectively, compare well with those obtained in similar studies by IMP (2006) and Almanza et al. (2012). We have used fuel flow flux $=1.174 \mathrm{~m}^{3} / \mathrm{s}$ for our estimations in this study. The values obtained for $E F_{C O}$ and $E F_{C O 2}$ compare well with those from United Kingdom Offshore Association (UKOA), Talebi et al. (2014) and USEPA (1995).

Table 2a: Emission Factor (EF) for soot

\begin{tabular}{|c|c|c|c|}
\hline Reference & EF $\left(\mathrm{kg} / 10^{3} \mathrm{~m}^{3}\right.$ of fuel) & EF (kg/s) & Type of fuel \\
\hline $\begin{array}{c}\text { (USEPA, 1995) } \\
\text { (Johnson } \text { et al ., 2013) } \\
\text { (McEwen and Johnson, 2012) }\end{array}$ & $\begin{array}{c}0,0.9,4.2,6.4 \\
- \\
0.51\end{array}$ & $\begin{array}{c}- \\
6.7 \times 10^{-5} \\
-\end{array}$ & $\begin{array}{l}80 \% \text { propylene } 20 \% \text { propane } \\
\text { field measurement } \\
85.2 \% \text { methane, } 7.1 \% \text { ethane, } 2 \% \\
\text { propane, } 1.4 \% \text { n-butane }\end{array}$ \\
\hline$(\mathrm{IMP}, 2006)^{\mathrm{a}}$ & - & $3.37 \times 10^{-3}$ & $\begin{array}{lll}1 & 1 & -\end{array}$ \\
\hline (Almanza et al., 2012) & - & $2.24 \times 10^{-4}$ & - \\
\hline (Johnson et al., 2011) & - & $2.0 \pm 0.66 \times 10^{-3}$ & - \\
\hline GAINS (Stohl et al., 2013) & 1.6 & - & modelling \\
\hline This work - Fuel I & 0.58 & $6.9 \times 10^{-4}$ & associated gas \\
\hline Fuel II & 1.73 & $2.02 \times 10^{-3}$ & associated gas \\
\hline
\end{tabular}

a quoted from Almanza et al. (2012)

Table 2b: Emission factors for carbon monoxide and carbon dioxide

\begin{tabular}{|c|c|c|c|c|c|c|}
\hline References & $\begin{array}{c}\mathrm{CO} \\
(\mathrm{kg} / \mathrm{kg})\end{array}$ & $\mathrm{CO}_{2}(\mathrm{~kg} / \mathrm{kg})$ & $\begin{array}{c}\mathrm{CO} \\
(\mathrm{kg} / \mathrm{s})\end{array}$ & $\mathrm{CO}_{2}(\mathrm{~kg} / \mathrm{s})$ & $\begin{array}{c}\mathrm{CO} \\
(\mathrm{kg} / \mathrm{GJ})\end{array}$ & $\begin{array}{c}\mathrm{CO}_{2} \\
(\mathrm{~kg} / \mathrm{GJ})\end{array}$ \\
\hline (EEMS, 2008) & 0.0067 & 2.8 & - & - & - & - \\
\hline (USEPA, 1995) & - & - & - & - & 0.16 & 50.2 \\
\hline $\begin{array}{c}\text { The Norwegian Oil Industry } \\
\text { Association b }\end{array}$ & - & - & - & - & 0.026 & 63.6 \\
\hline $\begin{array}{c}\text { (Talebi } \text { et al } ., 2014) \\
\begin{array}{c}\text { United Kingdom Offshore } \\
\text { Association (UKOA) }\end{array}\end{array}$ & - & - & - & - & $0.1-0.59$ & $49.0-51.6$ \\
\hline This work (fuel I) & 0.0082 & 2.62 & 0.007 & 2.32 & 0.24 & 61.8 \\
\hline This work (fuel II) & 0.0092 & 2.87 & 0.013 & 3.93 & 0.26 & 74.3 \\
\hline
\end{tabular}

buoted from Talebi et al. (2014).

The graphs in Figures 4 and 5 show the 2dimensional variation of $\mathrm{EF}_{\text {soot }}, \mathrm{EF}_{\mathrm{CO}}$ and $\mathrm{EF}_{\mathrm{CO} 2}$ with equivalence ratio, $\phi$ and flue gas exit velocity, $V_{s}$. The graphs also show the variation of CCE with $\phi$ for the two fuel compositions used in this study. The exit velocity of the flue gas was varied by varying the volume flux $\left(\mathrm{m}^{3} / \mathrm{s}\right)$ of the fuel gas while the stack diameter is kept constant. Soot given off is dependent on both the equivalent ratio and the flame dynamics characteristics as measured by the fire Froude number. Low values of $V_{s}$, (for example, $2.0 \mathrm{~m} / \mathrm{s}$ ) can produce very sooty flames at higher values of $\phi$. At high flue gas exit velocity $(>6 \mathrm{~m} / \mathrm{s})$ and high $\phi(>1.1)$, the low value of soot emitted is probably due to some of the fuel 'escaping' unburned as a result of the high exit velocity and low amount of oxygen available (see Figs. 4 and 5).

The heavier the fuel gas the more oxygen needed for combustion. The molar masses of fuel compositions I and II are 18.5 and 28.6, respectively. A difference of 0.04 in the value of $\mathrm{C}: \mathrm{H}$ for fuel composition I and II results in an increase of $E F_{\text {soor }} E F_{C O}$ and $E F_{C O 2}$ by factors of $\sim 3$, $\sim 1.4$ and $\sim 1.7$, respectively. This underpins the 
importance of fuel composition in the estimation of pollutants emission from the combustion of hydrocarbons. The importance of a qualitative idea of the amount of air available for the combustion, the fuel gas flow rate and stack characteristics (diameter) are also demonstrated with the wide variation of emission quantities.

These emission factor $(\mathrm{EF})$ estimations $\left(\mathrm{CO}, \mathrm{CO}_{2}\right.$, soot) have been coded into MATLAB as a pre- processor for dispersion modeling software. The user supplies the fuel composition (preferably, in percentage molar composition), equivalence ratio $(\phi)$, ambient temperature, atmospheric pressure, stack diameter and fuel gas flow flux $\left(\mathrm{m}^{3} / \mathrm{s}\right)$. The pre-processor generates estimates for the yields of soot, $\mathrm{CO}_{2}$, and $\mathrm{CO}$. Other combustion parameters generated by the pre-processor are flame length $(\mathrm{m})$, net heat released $(\mathrm{MJ} / \mathrm{s})$ and flue gas exit velocity $(\mathrm{m} / \mathrm{s})$.
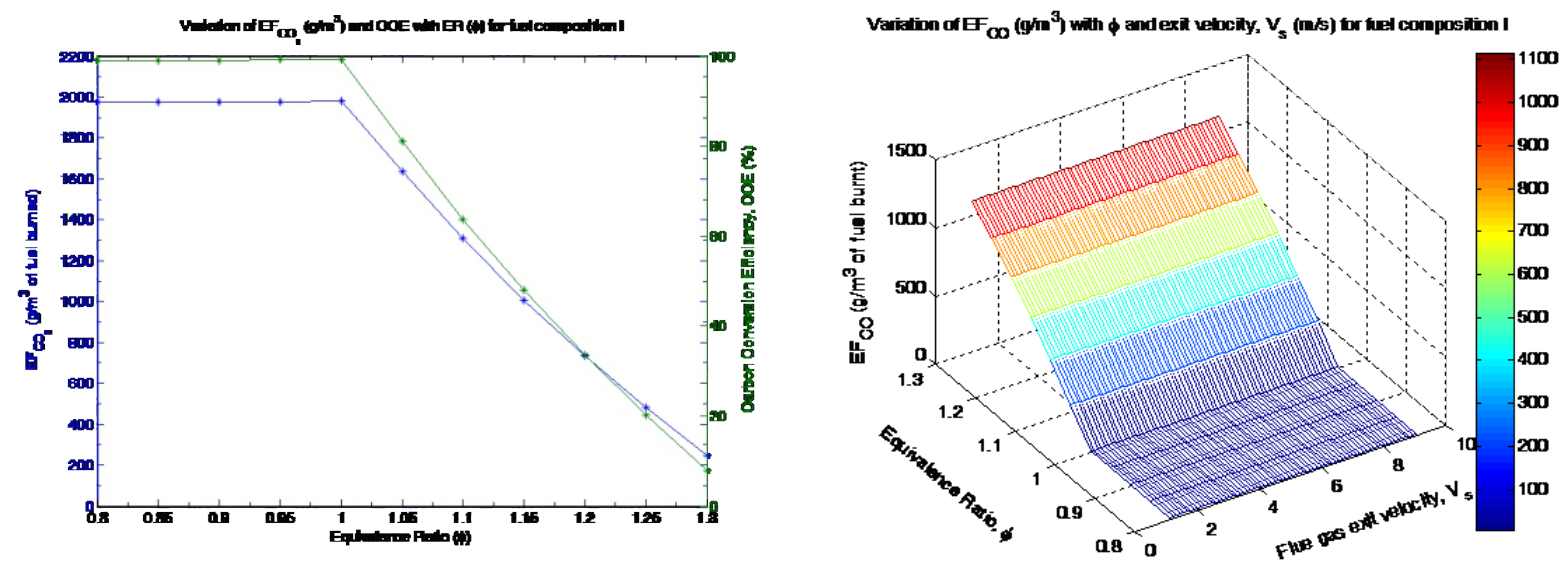

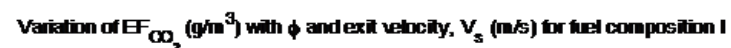
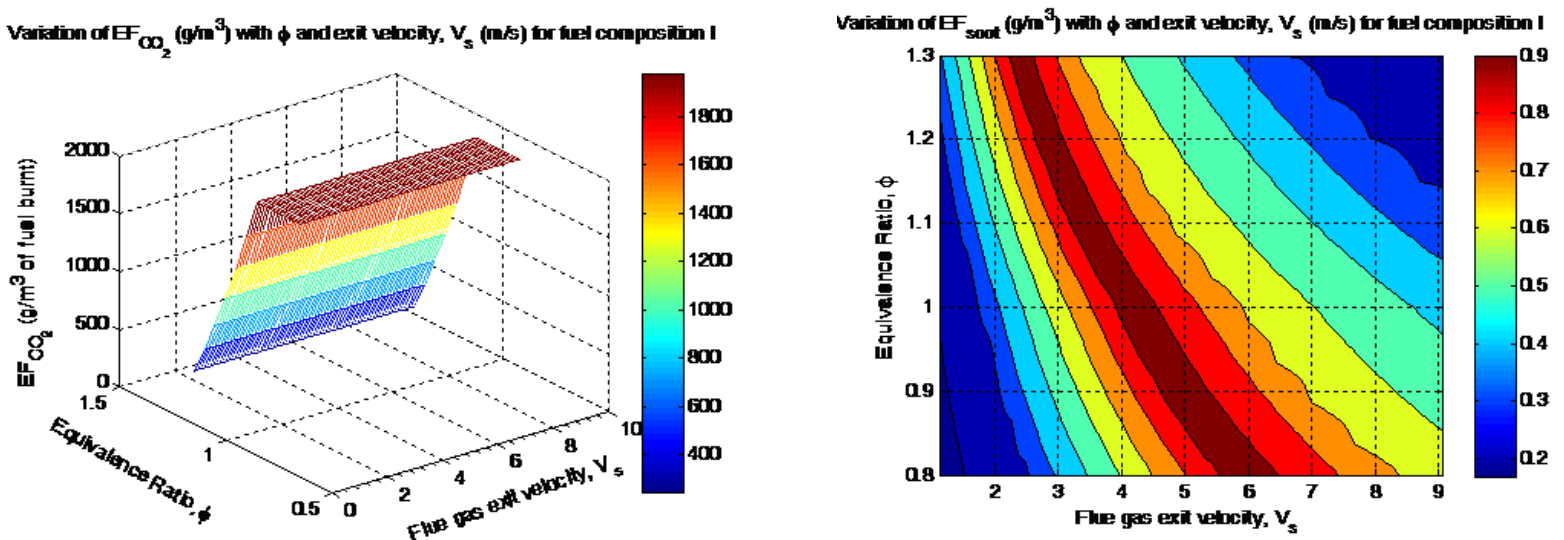

Figure 4: Variation of CCE, $\mathrm{CO}_{2}, \mathrm{CO}$ and soot yields with $\phi$ and flue gas exit velocity for fuel composition I. 

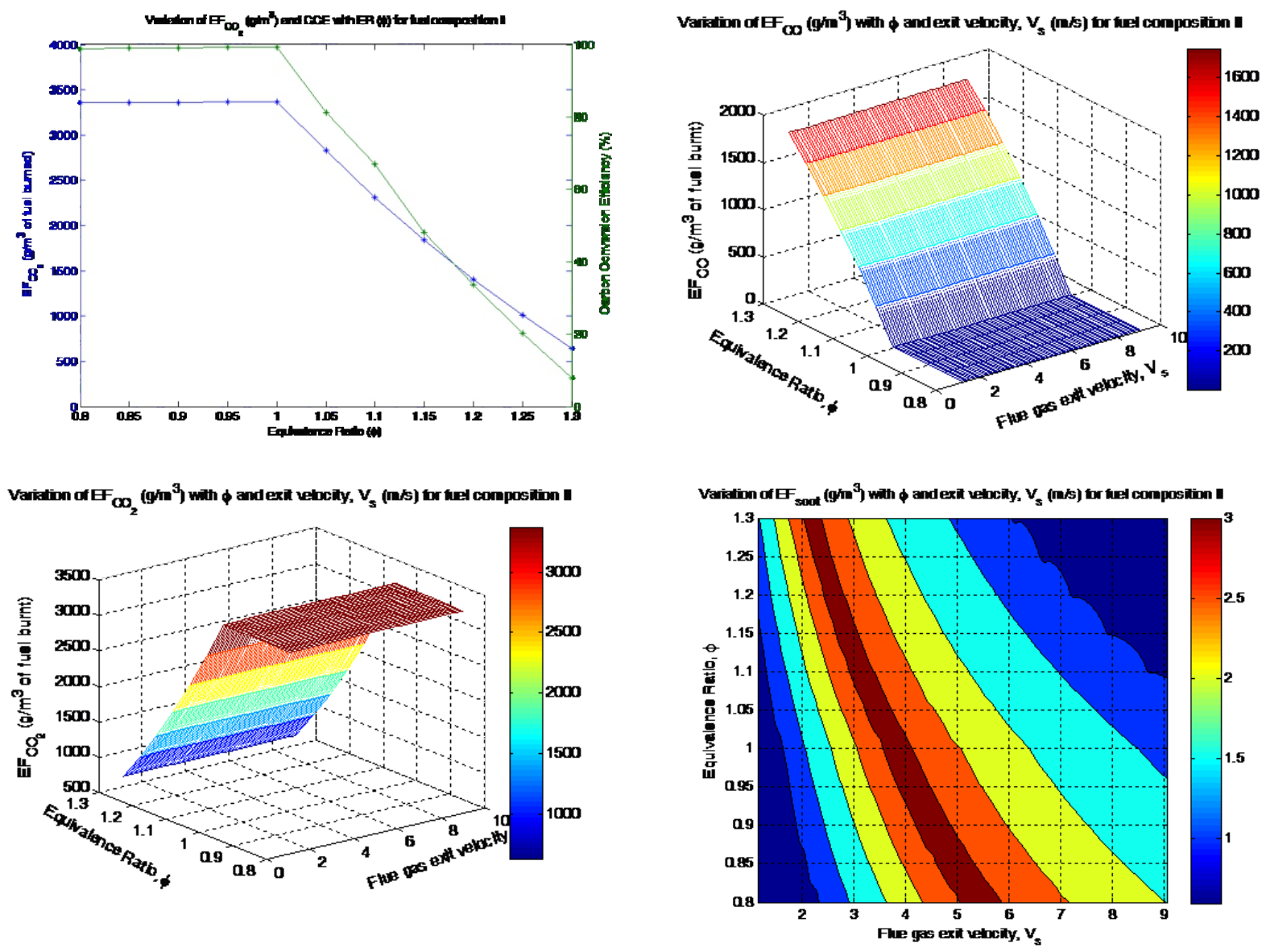

Figure 5: Variation of CCE, $\mathrm{CO}_{2}, \mathrm{CO}$ and soot yields with $\phi$ and exit velocity for fuel composition II.

\section{CONCLUSION}

This work developed a simple self-consistent technique to estimate the emission factors of carbon-containing emissions from a typical gas flare. The technique factors in the effect of fuel composition and flame dynamics characteristics. The dependence of pollutants emission on fuel gas composition, fuel flow flux, stack characteristics and equivalence ratio, $\phi$, were demonstrated using two fuel gases of varying composition. The mass-weighted carbon to hydrogen ratio $(\mathrm{C}: \mathrm{H})$ of fuel gas, a function of the fuel composition, plays a very prominent role in the nature and quantity of pollutants emitted from the combustion process. The use of generalized emission factors for carbon-containing pollutants emitted from gas flares, a highly varying source of pollutants, could be responsible for the disparities in model simulations and measurements in prominent gas flaring regions of the world.

The estimates from this pre-processor can be further validated and improved upon by more elaborate field measurements from gas flaring sites rather than lab-based or pilot-scale studies. It (pre-processor) could be made more accurate when other experimental works can provide similar data to better constrain ' $r C$ Presently, the study by McEwen and Johnson is the only known study that can be applied directly in our proposed estimation technique. Experimental work that gives soot yield from hydrocarbon, typically alkane, combustion as a function of a combustion (fuel or flame) dynamics parameter is quite suitable for the method proposed here. The preprocessor developed in this study finds application in the oil and gas industry. It can support the work of environmental officers in the oil and gas industry to estimate pollutants emission for the combustion of associated gas, especially in typical 'real world' gas flares.

\section{ACKNOWLEDGEMENT}

Olusegun G. Fawole is highly grateful to the UK 
Department for International Development (DFID) for funding his $\mathrm{PhD}$ studies through the UK Commonwealth Scholarships Commission (CSCUK) NGCA-2013-70.

\section{REFERENCES}

Abdulkareem, A.S., Afolabi, A.S., Jimoh, A., Uthman, H. and Odigure, J., 2012. Oil Exploration and Climate Change: A Case Study of Heat Radiation from Gas Flaring in the Niger Delta Area of Nigeria. INTECH open science, Chapter 1.

Akeredolu, F. and Sonibare, J., 2004. A review of the usefulness of gas flares in air pollution control. Management of Environmental Quality: An International Journal, 15(6): 574-583.

Almanza, V., Molina, L. and Sosa, G., 2012. Soot and SO 2 contribution to the supersites in the MILAGRO campaign from elevated flares in the Tula Refinery. Atmospheric Chemistry and Physics, 12(21): 10583-10599.

Becker, H. and Liang, D., 1982. Total emission of soot and thermal radiation by free turbulent diffusion flames. Combustion and Flame, 44(1): 305-318.

Becker, H. and Yamazaki, S., 1978. Entrainment, momentum flux and temperature in vertical free turbulent diffusion flames. Combustion and Flame, 33:123-149.

Beychok, M.R., 1994. Fundamentals of stack gas dispersion, 63. Milton R. Beychok Irvine.

Bishop, G. and Stedman, D., 1996. Measuring the emissions of passing cars. Accounts of Chemical Research, 29(10): 489-495.

Bond, T.C., Doherty, S.J., Fahey, D., Forster, P., Berntsen, T., DeAngelo, B., Flanner, M., Ghan, S., Kärcher, B. and Koch, D., 2013. Bounding the role of black carbon in the climate system: A scientific assessment. Journal of Geophysical Research: Atmospheres, 118(11): 5380-5552.

Bourguignon, E., Johnson, M. and Kostiuk, L., 1999. The use of a closed-loop wind tunnel for measuring the combustion efficiency of flames in a cross flow. Combustion andflame, 119(3):319-334.

Canteenwalla, P., Thomson, K., Smallwood, G. and Johnson, M., 2007. Soot emissions from turblent diffusion flames burning simple alkane fuels. http://nparc.cistiicist.nrc-cnrc.gc.ca/npsi/ctrl?action $=$ shwart\&index $=$ an\&req $=8894822 \&$ lang $=$ en (last accessed on February 19, 2015)

Castineira, D. and Edgar, T.F., 2006. CFD for simulation of steam-assisted and airassisted flare combustion systems. Energy \& fuels, 20(3): 1044-1056.

Chow, J.C., Watson, J.G., Lu, Z., Lowenthal, D.H., Frazier, C.A., Solomon, P.A., Thuillier, R.H. and Magliano, K., 1996. Descriptive analysis of PM2.5 and PM10 at regionally representative locations during SJVAQS/AUSPEX. Atmospheric Environment, 30(12):2079-2112.

Delichatsios, M., 1993. Transition from momentum to buoyancy-controlled turbulent jet diffusion flames and flame height relationships. Combustion and flame, 92(4):349-364.

Djuricin, S., Pataki, D.E. and Xu, X., 2010. A comparison of tracer methods for quantifying $\mathrm{CO} 2$ sources in an urban region. Journal of Geophysical Research: Atmospheres (1984-2012), 115(D11).

Edwards, P.M., Brown, S.S., Roberts, J.M., Ahmadov, R., Banta, R.M., deGouw, J.A., Dube, W.P., Field, R.A., Flynn, J.H., Gilman, J.B., Graus, M., Helmig, D., Koss, A., Langford, A.O., Lefer, B.L., Lerner, B.M., Li, R., Li, S.-M., McKeen, S.A., Murphy, S.M., Parrish, D.D., Senff, C.J., Soltis, J., Stutz, J., Sweeney, C., Thompson, C.R., Trainer, M.K., Tsai, C., Veres, P.R., Washenfelder, R.A., Warneke, C., Wild, R.J., Young, C.J., Yuan, B. and Zamora, R., 2014. High winter ozone pollution from carbonyl photolysis in an oil and gas basin. Nature, advance online publication.

EEA, 2006. Waste incineration: Flaring in gas and oil extraction, Emission Inventory Guidebook, European Environment Agency, Copenhagen, Denmark.

EEMS, 2008. Atmospheric emissions calculations, Environmental Emissions Monitoring System, United Kingdom.

Elvidge, C.D., Zhizhin, M., Baugh, K., Hsu, F.-C. and Ghosh, T., 2015. Methods for Global Survey of Natural Gas Flaring from Visible Infrared Imaging Radiometer Suite Data. Energies, 9(1): 14. 
Fawole, O., Cai, X.-M. and MacKenzie, A., 2016. Gas flaring and resultant air pollution: A review focusing on Black Carbon. Environmental Pollution, 216: 182-197. doi:10.1016/j.envpol.2016.05.075.

Fawole, O.G., Cai, X. and MacKenzie, A., 2017. Evidence for a gas-flaring source of alkanes leading to elevated ozone in air above West Africa. African Journal of Environmental Science and Technology, 11(10): 532-543.

Feichter, J. and Stier, P., 2012. Assessment of black carbon radiative effects in climate models. Wiley Interdisciplinary Reviews: Climate Change, 3(4):359-370.

Flagan, R.C. and Seinfeld, J.H., 2012. Fundamentals of air pollution engineering. Courier Dover Publications.

Fortner, E., Brooks, W., Onasch, T., Canagaratna, M., Massoli, P., Jayne, J., Franklin, J., Knighton, W., Wormhoudt, J. and Worsnop, D., 2012. Particulate Emissions Measured During the TCEQ Comprehensive Flare Emission Study. Industrial \& Engineering Chemistry Research, 51(39): 12586-12592.

GGFR, 2012. Estimated Flared Volumes from Satellite Data, 2007-2011., Global Gas Flaring Reduction, http://go.worldbank .org/G2OAW2DKZ0 (last accessed on January 9, 2015).

Gilman, J., Lerner, B., Kuster, W. and De Gouw, J., 2013. Source signature of volatile organic compounds from oil and natural gas operations in northeastern Colorado. Environmental science \& technology, 47(3): 1297-1305.

Huang, K., Fu, J.S., Prikhodko, V.Y., Storey, J.M., Romanov, A., Hodson, E.L., Cresko, J., Morozova, I., Ignatieva, Y. and Cabaniss, J., 2015. Russian anthropogenic black carbon: Emission reconstruction and Arctic black carbon simulation. Journal of Geophysical Research: Atmospheres, 120. 10.1002/2015JD023358.

IEA, 2012. IEA statistics: Natural gas information, International Energy Agency, Paris, France.

IMP, 2006. Estudio de las emisiones de la zona industrial de Tula y su impacto en la calidad del aire regional, PS-MA-IF-
F21393-1, IMP, Mexico.

Ismail, O.S. and Umukoro, G.E., 2016. Modelling combustion reactions for gas flaring and its resulting emissions. Journal of King Saud University-Engineering Sciences, 28(2): 130140.

Jacobson, M.Z., 2002. Control of fossil?fuel particulate black carbon and organic matter, possibly the most effective method of slowing global warming. Journal of Geophysical Research: Atmospheres (1984-2012), 107(D19): ACH 16-1-ACH 16-22.

Johnson, M., Devillers, R. and Thomson, K., 2013. A Generalized Sky-LOSA Method to Quantify Soot/Black Carbon Emission Rates in Atmospheric Plumes of Gas Flares. Aerosol Science and Technology, 47(9): 1017-1029.

Johnson, M. and Kostiuk, L., 2000. Efficiencies of low-momentum jet diffusion flames in crosswinds. Combustion and Flame, 123(1): 189-200.

Johnson, M.R., Devillers, R.W. and Thomson, K.A., 2011. Quantitative field measurement of soot emission from a large gas flare using Sky-LOSA. Environmental science \& technology, 45(1): 345-350.

Kirchstetter, T.W., Harley, R.A., Kreisberg, N.M., Stolzenburg, M.R. and Hering, S.V., 1999. On-road measurement of fine particle and nitrogen oxide emissions from lightand heavy-duty motor vehicles. Atmospheric Environment, 33(18): 29552968.

Kostiuk, L., Johnson, M. and Thomas, G., 2004. University Of Alberta Flare Research Project: final report November 1996$\mathrm{S}$ e p t e m b e r 2004 . 2, http://www.mece.ualberta.ca/groups/co mbustion/flare/papers/Final\%20Report 2004.pdf.

Leahey, D.M., Preston, K. and Strosher, M., 2001. Theoretical and observational assessments of flare efficiencies. Journal of the Air \& Waste Management Association, 51(12): 1610-1616.

Li, C., Hsu, N.C., Sayer, A.M., Krotkov, N.A., Fu, J.S., Lamsal, L.N., Lee, J. and Tsay, S.-C., 2016. Satellite observation of pollutant 
emissions from gas flaring activities near the Arctic. Atmospheric Environment, 133: 111.

Liousse, C., Keita, S., Granier, L., Granier, C., Elvidge, C.D., Elguindi, N. and Law, K., 2019. Flaring emissions in Africa: Distribution, evolution and comparison with current inventories. Atmospheric environment, 199: 423-434.

McAllister, S., Chen, J.-Y. and Fernandez-Pello, A.C., 2011. Fundamentals of combustion processes. Springer.

McDaniel, M. and Tichenor, B.A., 1983. Flare efficiency study, US Environmental Protection Agency, Industrial Environmental Research Laboratory, http://www.tceq.state.tx.us/assets/publi c/implementation/air/rules/Flare/Reso urce_1.pdf.

McEwen, J.D. and Johnson, M.R., 2012. Black carbon particulate matter emission factors for buoyancy-driven associated gas flares. Journal of the Air \& Waste Management Association, 62(3): 307-321.

Obanijesu, E., Adebiyi, F., Sonibare, J. and Okelana, O., 2009. Air-borne SO2 Pollution Monitoring in the Upstream Petroleum Operation Areas of NigerDelta, Nigeria. Energy Sources, Part A, 31(3): 223-231.

Ramana, M., Ramanathan, V., Feng, Y., Yoon, S., Kim, S., Carmichael, G. and Schauer, J., 2010. Warming influenced by the ratio of black carbon to sulphate and the blackcarbon source. Nature Geoscience, 3(8): 542545.

Ramanathan, V. and Carmichael, G., 2008. Global and regional climate changes due to black carbon. Nature Geoscience, 1(4): 221-227.

Santos, F., Fraser, M. and Bird, J., 2014. Atmospheric black carbon deposition and characterization of biomass burning tracers in a northern temperate forest. Atmospheric Environment, 95: 383-390.

Schug, K., Manheimer-Timnat, Y., Yaccarino, P. and Glassman, I., 1980. Sooting behavior of gaseous hydrocarbon diffusion flames and the influence of additives. Combustion Science and Technology, 22(5-6): 235-250.

Schwarz, J.P., Holloway, J.S., Katich, J.M., McKeen, S., Kort, E.A., Smith, M.L., Ryerson, T.B.,
Sweeney, C. and Peischl, J., 2015. Black carbon emissions from the Bakken Oil and Gas Development region. Environmental Science \& Technology Letters, 2(10): 281-285.

Seinfeld, J., 2008. Atmospheric science: Black carbon and brown clouds. Nature Geoscience, 1(1): 15-16.

Siegel, K., 1980. Degree of conversion of flare gas in refinery high flares, Thesis $\mathrm{PhD}$ in Engr. Science, Chemical Engr. Dept., Univ. of Karlesruhe, Germany (February, 1980).

Sivathanu, Y. and Faeth, G.M., 1990. Soot volume fractions in the overfire region of turbulent diffusion flames. Combustion and Flame, 81(2): 133-149.

Sonibare, J., Adebiyi, F., Obanijesu, E. and Okelana, O., 2010. Air quality index pattern around petroleum production facilities. Management of Environmental Quality: An International Journal, 21(3): 379392.

Sonibare, J.A. and Akeredolu, F.A., 2004. A theoretical prediction of non-methane gaseous emissions from natural gas combustion. Energy Policy, 32(14): 16531665.

Stohl, A., Klimont, Z., Eckhardt, S., Kupiainen, K., Shevchenko, V., Kopeikin, V. and Novigatsky, A., 2013. Black carbon in the Arctic: the underestimated role of gas flaring and residential combustion emissions. Atmospheric Chemistry and Physics, 13(17): 8833-8855.

Stone, D.K., Lynch, S.K., Pandullo, R.F., Evans, L.B. and Vatavuk, W.M., 1992. Flares. Part I: Flaring Technologies for Controlling VOC-Containing Waste Streams. Journal of the Air \& Waste Management Association, 42(3):333-340.

Strosher, M.T., 2000. Characterization of emissions from diffusion flare systems. Journal of the Air \& Waste Management Association, 50(10): 1723-1733.

Talebi, A., Fatehifar, E., Alizadeh, R. and Kahforoushan, D., 2014. The Estimation and Evaluation of New $\mathrm{CO}, \mathrm{CO} 2$, and NOx Emission Factors for Gas Flares Using Pilot Scale Flare. Energy Sources, Part A: Recovery, Utilization, and 
EnvironmentalEffects, 36(7): 719-726.

Tegen, I., Hollrig, P., Chin, M., Fung, I., Jacob, D. and Penner, J., 1997. Contribution of different aerosol species to the global aerosol extinction optical thickness: Estimates from model results. Journal of Geophysical Research: Atmospheres (19842012), 102(D20): 23895-23915.

Torres, V.M., Herndon, S. and Allen, D.T., 2012a. Industrial flare performance at low flow conditions. 2. Steam-and air-assisted flares. Industrial \& Engineering Chemistry Research, 51(39): 12569-12576.

Torres, V.M., Herndon, S., Kodesh, Z. and Allen, D.T., 2012b. Industrial flare performance at low flow conditions. 1. Study overview. Industrial \& Engineering Chemistry Research, 51(39): 12559-12568.

USEPA, 1995. AP 42-Compilation of air pollutant emission factors. Section 13.5: Industrial flares, U.S Environmental Protection Agenecy, Office of Air quality planning and standards, Research Triangle Park, NC. http://www.epa.gov/ttn/ chief/ap42/ch13/final/c13s05.pdf.

USEPA, 2014. AP 42-Compilation of air pollutant emission factors. Section 13.5: Industrial flares, U.S Environmental Protection Agenecy, Office of Air quality planning and standards, Research Triangle Park, NC.

Weyant, C.L., Shepson, P.B., Subramanian, R., Cambaliza, M.O., Heimburger, A., McCabe, D., Baum, E., Stirm, B.H. and Bond, T.C., 2016. Black carbon emissions from associated natural gas flaring. Environmental Science \& Technology, 50(4): 2075-2081. 